\title{
Cyberspace as the Public Space of Virtual Communities: A Study of Virtual Communities Members' Behavior as an Approach to the Physical Version of Cyberspace
}

\author{
By Raed Salem Al Tal ${ }^{*} \&$ Reem AliBarakat ${ }^{\dagger}$
}

\begin{abstract}
This research deals with the cyberspace as the public space of virtual communities. It assumes that the involvement in virtual communities has changed people's conception towards their response to the sense of space. It aims at investigating the effective properties of the cyberspace, and then the possibility of translating these properties into applicable and efficient features in the reality of the physical space. To examine the assumptions of the research, an e-survey was conducted on a sample of architectural students at Jordan University of Science and Technology (JUST), who share the same physical space in their college and a cyberspace of their Facebook group - "ArchiGroup". The research reveals students' tendency to feel the reality of the virtual communities, and its milieu-cyberspace. Based on the results, the findings of the research recommend designers to consider the success of cyberspace while designing the physical versions. In addition, the research seems applicable on different models that employ different variables to investigate a mechanism of producing a physical space as productive as the cyber version, achieving the real version of participation.
\end{abstract}

\section{Introduction}

Early researchers, like Hollingshead 1949, discovered that the social stratification was, inequitably, the most effective factor, which hides the true concept of community under the nominally cohesive communities within specific spaces. ${ }^{1}$ Relationships within societies were generally hierarchical, with specialized exploitation bonds, with a deep divide between factions. ${ }^{2}$ It produces a distorted conception of community. ${ }^{3}$ The idea of a local community implies the potential basis for mutual participation and involvement between people who live in an area which develop some sense of shared identity. ${ }^{4}$ Contemporary sociologists prefer to rely more on the social processes of interaction and reciprocity operating within groups, rather than the boundaries of locality. ${ }^{5}$ It is

*Assistant Professor, German Jordanian University, Jordan.

${ }^{\dagger} \mathrm{PhD}$ Candidate, Leeds University, UK.

1. A. B. Hollingshead, Elmtown's Youth, The Impact of Social Classes on Adolescents (New York: John Wiley and Sons, Inc., 1949), 49.

2. B. Wellman and S. D. Berjowitz (Editors), Social Structures: A Network Approach (New York, London: Cambridge University Press, 1988), 2.

3. S. Brint, M. F. Contreras and M. T. Matthews, "Socialization Messages in Primary Schools: An Organizational Analysis," Sociology of Education 74, no. 3 (2001): 157-180.

4. G. Crow and A. Graham, Community Life: An Introduction to Local Social Relations (New York, USA: Harvester-Wheatsheaf, 1994), 70.

5. Ibid, 75. 
just because communities are no longer restricted by geography. Community became more than a place.

\section{Towards a New Concept of Community - Imagining a Community}

Mass media demonstrated that virtually all of the hallmarks of geographic community could be simulated. In a mass-mediated world, it will be substantially, if not wholly, replicated. ${ }^{6}$ The changes in computer-mediated communication currently under way are no different in this regard. The concept of community becomes much larger than place, and a transmutation of the concept of 'community' into 'social networks' is produced. ${ }^{7}$ This connection to the new concept of social network analytic perspective of community has stresses the functioning of primary ties over notions of local solidarity. It is as Bender (1978) defined it: "a network of social relations marked by mutuality and emotional bonds." $" 8$

\section{Physical Public Space}

Space is a continuous area or expanse that is free, available, or unoccupied. It is a mathematical concept generally regarded as a set of points having some specified structure with the dimension of height, depth, and width within which all things exist and move. This definition has a social dimension of freedom to live, think, and develop in a way that suits one. Physically, this concept is applied to both architectural and urban spaces, which are occupied to exist and move within, creating opportunities to establish a social network and to hold activities. In the urban context, this word takes the conception of 'open space': An area of land that is not occupied by buildings. This area has a social dimension that tied its notion to people who access and use it. According to Rakhshandehroo et al. (2017) public space is a social space that is generally open and accessible - either physically (roads, public squares, parks ...etc.) or visually (advertising facades), to people. ${ }^{9}$

\section{Towards A New Concept of Space - Cyberspace}

Cyberspace, the world that lies beyond our computer screens in the vast network of computers, is a new space, a new home of mind, which is being

6. A. M. Muniz, Jr. and T. C. O'Guinn, "Brand Community,” Journal of Consumer Research 27, no. 4 (2001): 412-432.

7. Ibid.

8. T. Bender, Community and Social Change in America (New Brunswick, New Jersey: Rutgers University Press, 1978).

9. M. Rakhshandehroo, M. J. Mohd Yusof and A. Sahrakar, "Terminology of Urban Open and Green Spaces," $11^{\text {th }}$ ASEAN Postgraduate Seminar, APGS 2017 (Faculty of Built Environment, University of Malaya, Malaysia, 2017). 
created now. ${ }^{10}$ It became an essential part of our lives. More than a decade after the portals of the World Wide Web opened to the public, cyberspace is now witnessing the true emergence as a powerful personal and social phenomenon as described by William J. Mitchel with "Spatial" and "Antispatial."11

The limitation on computer networks uses, in its early days, made the describing of Internet as a space and sites as places seems far-fetched. This has changed with the accelerated growth of the computing process, converting the cyberspace sites from a places where we just look 'at' them, to those we feel present ' $i{ }^{\prime}$ ' them. ${ }^{12}$ It is now a space, albeit an abstract and virtual one, but an endless expanse of space: open, free, replete with possibility. ${ }^{13}$ The cyber-version of the communities, which started with the spread of e-mail using, has burgeoned and continued to grow as the possibilities of used features developed. The expand of possibilities of visual, vocal and text-contacting, and the chances to share statements, photos and videos have developed several versions of communities on blogs, wikis, messengers and social network sites - e.g. Facebook and twitter. The main turning point, which has transformed social communication in the history of social network sites, was the foundation of Facebook.

\section{Literature Discussions - Cyberspace Meets/Vs. Reality}

\section{Cyberspace and Architecture}

According to Marcos Novak "cyberspace itself is architecture but it also contains architecture", yet he states, "the relationship between architecture and cyberspace so far is not yet complete." ${ }^{14}$ Some of these relationship aspects could be seen in the freedom of Liquid Architecture from the factors like gravity, structures, materials, etc. Cyberspace exhorts and motivates the utopian architect to design spaces in the real world; spaces of great cybernetic influence, that is to say, spaces not only affected in appearance, but also in function by the ideas developed in cyberspace. Cyber spatial environment can't be, in any way, substitution for architecture in a real environment and needs to be recognized as a type with self-rights, but, the architecture of the "physical" will be influenced by the architecture of the "virtual."

As a space, we can envision virtual worlds as an extra dimension and not only as an alternative to the real world or a substitution of it. This allows us a new freedom of movement in the natural world. The transcendence of the physical "being" to the virtual world allows us to expand our way of operating in the

10. S. Doyle, M. Dodge and A. Smith, "The Potential of Web-Based Mapping and Virtual Reality/Technologies for Modelling Urban Environments," Computers, Environment and Urban Systems 22, no. 2 (1998): 137-155.

11. W. J. Mitchell. City of Bits: Space, Place, and the Infobahn (The MIT Press, 1996), 8.

12. Ibid.

13. D. Hunter, Cyberspace as Place and the Tragedy of the Digital Anticommons (California: California Law Review, Inc., 2003).

14. M. Novak, "Liquid Architectures in Cyberspace," in Cyberspace: First Steps (ed.) Michael Benedikt (Cambridge, Massachusetts/London, England: MIT Press, 1993), 248-251. 
physical world. While dealing with spaces we need to take into consideration that there is no presence of sensorial experience in the world itself but it only exists through the existence of the own body living now and here.

We should assume then, that Tele-presence is possible only when separating the body and the mind; sending the mind to a virtual environment while the body stays in the real environment. We have the possibility to exist simultaneously in the physical world as in the virtual world, since we can send our mind miles away, but hopelessly our body should remain in the same place. Therefore, the imagination of utopian architecture is not limited anymore by the physical reality." In addition, it is now the time of cyber effect on physical space. It is time to (actualize) the "virtual" in the "real" space.

\section{Objectives of Research}

This research focuses specifically on the understanding of the cyber communities' properties through the study of their members' behavior. The results are to be exploited in the defining of communication canals that allow individuals to act in this motivation in their cyber communities, and then translate them into physical synonyms. The final goal is to investigate a mechanism of producing a physical space as productive as the cyber one, and thus an access to the architectural version of 'participation.'

In terms of achieving the goal of this research, it is obvious the importance to examine the success of a community based on the intellectual and emotional convergence without physicist, or the efficiency of the long-term contact within high-density and short-term configurations pushed successively to be replaced by other configurations, in a very short and limited-effectiveness impact timeframe. These questions bear different possibilities which help us to recognize that the cyber community as a concept is still amorphous, especially with the fluctuations occurring in the development of this technique, developing a somewhat ambiguous vision to cyber communities.

Finally, in term of results, it is good to examine the reality of cyber communities' contribution in strengthening social relationships between individuals - such as thinking - in a way to appear as a process of enhancing the split views in the public sphere, versus their contribution in reducing cyber communities members' chances to interact with other members of the larger community. In addition, it is not deniable the mixing between the desire to communities of interest with the hope of a more erect and equitable one. The cyber communities' effect and adverse effect on the collectivism are to be discussed.

\section{The Applied Survey - Research Methodology and Result Discussion}

Both traditional and virtual communities are connected, since a well-based traditional networks can introduce more solid cyber one. At the same time, the opportunities of the cyber networks can overcome several obstacles in the 
traditional versions of social networks. Therefore, the personal and collective social experience of members is enhanced. This reciprocal relationship of affecting and affected by, is reflected on the members' conception of the space maintain their experience - both physical and cyber. Cyberspace users experience the superseding of traditional communication objects by the electronic one, keeping up the notion of space that saturates their ordinary everyday lives. People can, now, describe and assess their new space in a reference to that which they used to be more familiar.

Universities provide a milieu for social spaces, which are as important as the study spaces for students. Student social spaces are places where socializing and/or study occur in a relaxed setting that is not rigid and where a variety of social activities may co-exist with study and coursework. These social spaces are primarily in common areas, but also include spaces that are departmental controlled.

There are four types of activities hold in student social spaces: study, social, public assembly and casual activities. The characteristics of space change for each activity. For example: quite solitary spaces which are fit for long time use are suitable for study, while they have to be more flexible and changeable spaces which gather small groups to be a social activities holder space. Public assembly spaces have to be multipurpose which gather larger groups. Finally, casual meetings spaces are transitory in nature, which are founded usually at the edges of circulation routs. Each space may have any of these spaces, but it will be clearly characterized for one of the mentioned categories.

Like all public spaces and other common areas, student social spaces rely on the community to keep it satisfied and continuously developing in a flexible way. In such spaces, the community is the expert. They are a possible partner who could help to create a vision for the social space and be a source of feedback.

A group of the students in the College of Architecture and Design at Jordan University of Science and Technology (CAD) were selected to apply an e-survey, which aims at helping to find the relationships and differences between the imagined and real space and their communities. This group is shared members of both a traditional community, of the college family. The group acts in a physical space of the college's different facilities, and a virtual community, of the ArchiGroup - which acts in a cyberspace of Facebook.

The students interact formally and casually in the physical space of their college that was established as a part of the College of Engineering in 1979 and announced as an independent college in 2008. The college consists of three academic departments: Department of Architecture, Department of Urban Planning, and the Department of Design, offers different types of space for 988 students, 15 post-graduate students and 38 academic staff members to interact.

There are three main physical spaces: lecture rooms, indoor hallways casually known for the students as 'Squares', corridors and outdoor plazas. The students of this college are familiar with two types of educational spaces: lecture rooms and design studios where they can learn and interact (Figure 1). 

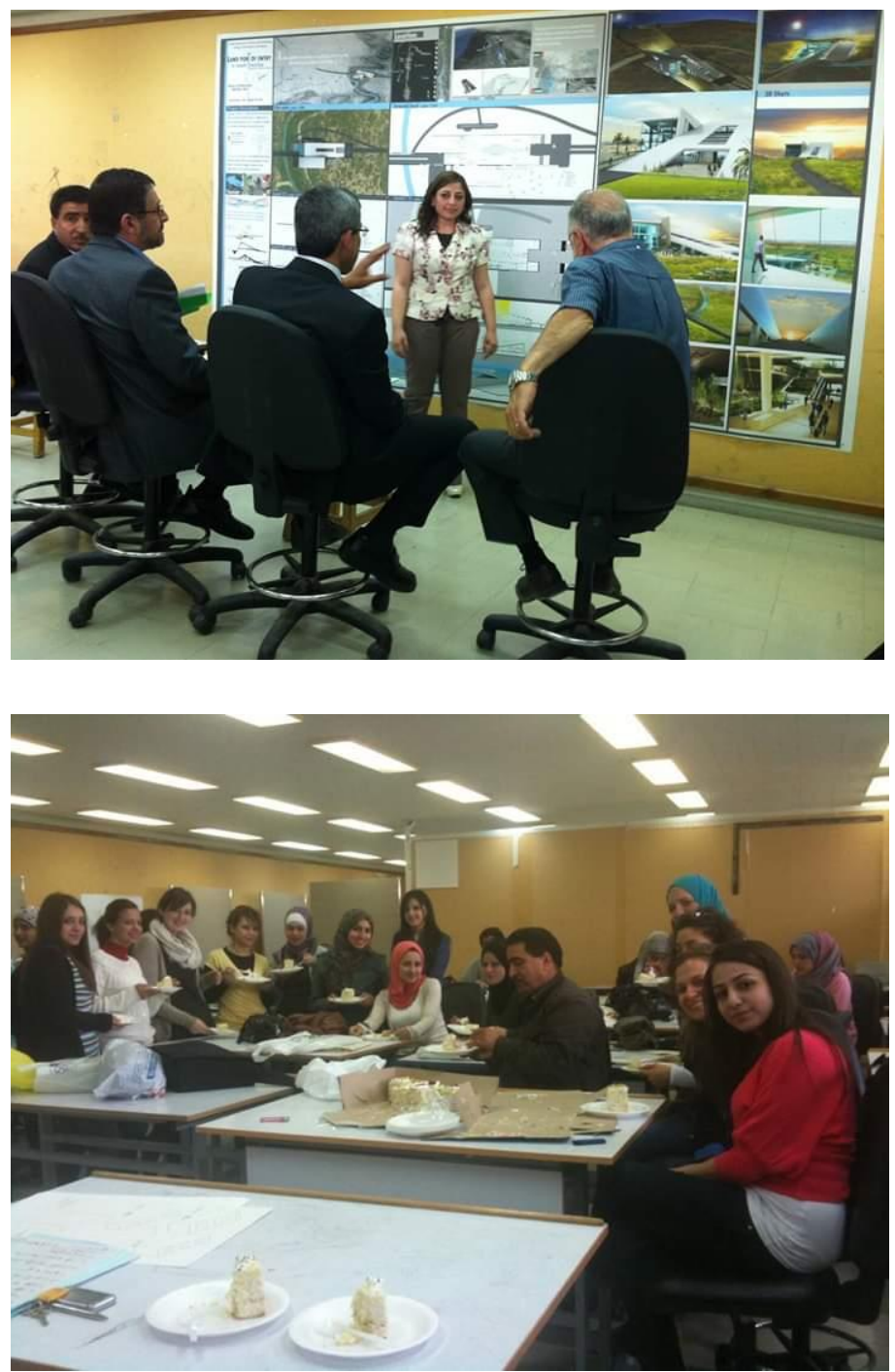

Figure 1. Design Studios where they can learn and Interact

Source: Authors.

This interaction, sometimes, extends to take place in the corridors and indoor hallway 'the square'. Nevertheless, these spaces seem to be more casual, and students used to interact within in nodes of sub-groups. Limited events are applied in the college indoor hallway, and larger ones are extend to take place in the outdoor plaza. In such events, interaction takes the form of direct and multidirectional channels (Figure 2). 

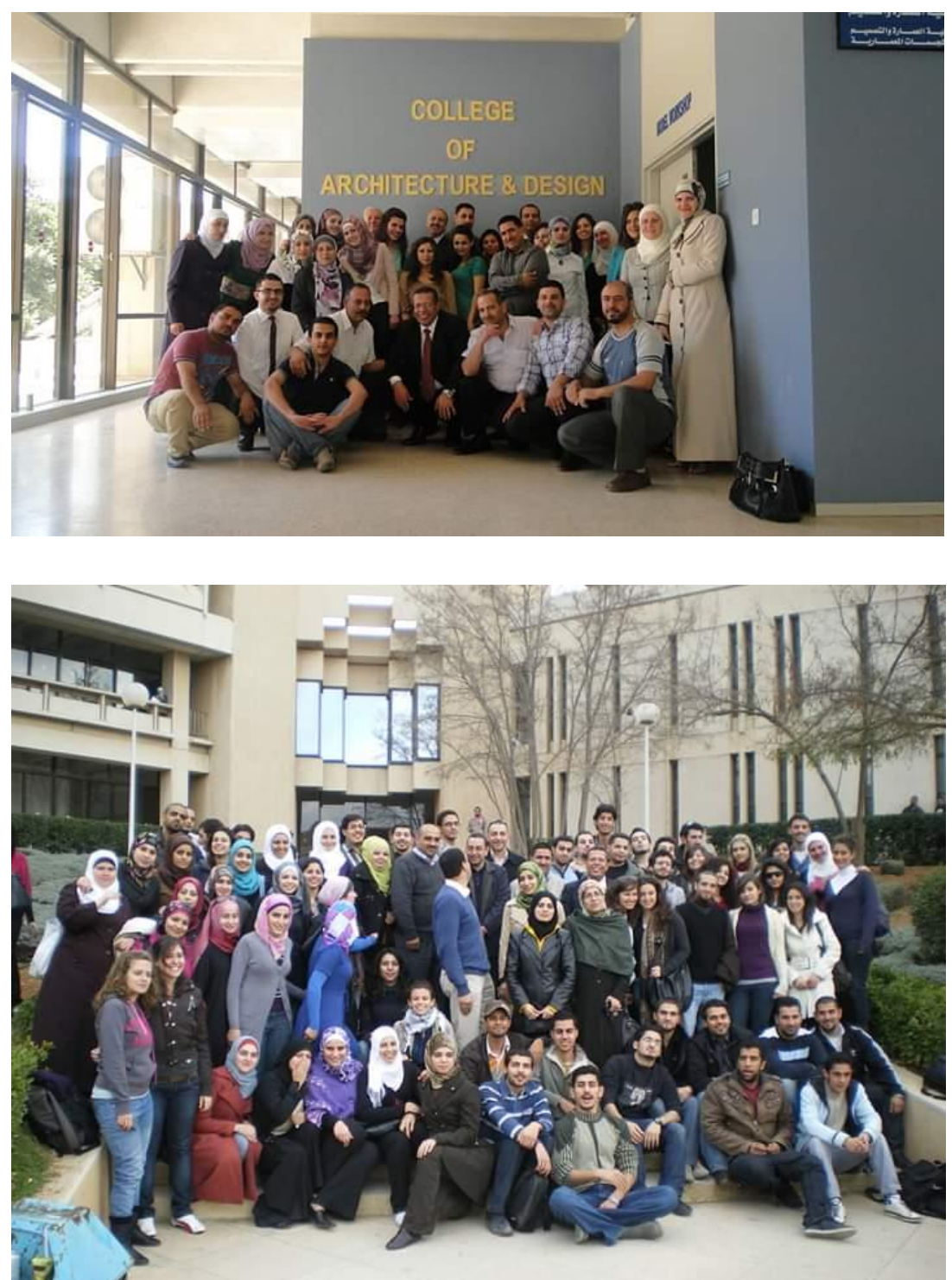

Figure 2. Interaction, Sometimes, Extends to Take Place in the Corridors and Indoor Hallway 'The Square'

Source: Authors.

In 2012, the students have created a virtual version of their community in the Facebook, within which they act almost most of what they do at the college. The ArchiGroup is a Facebook group of the students, $\mathrm{x}$-students and the staff of their college. This group is continuously growing and consists of 1438 members of the college family managed by five administrators (Figure 3 ). 


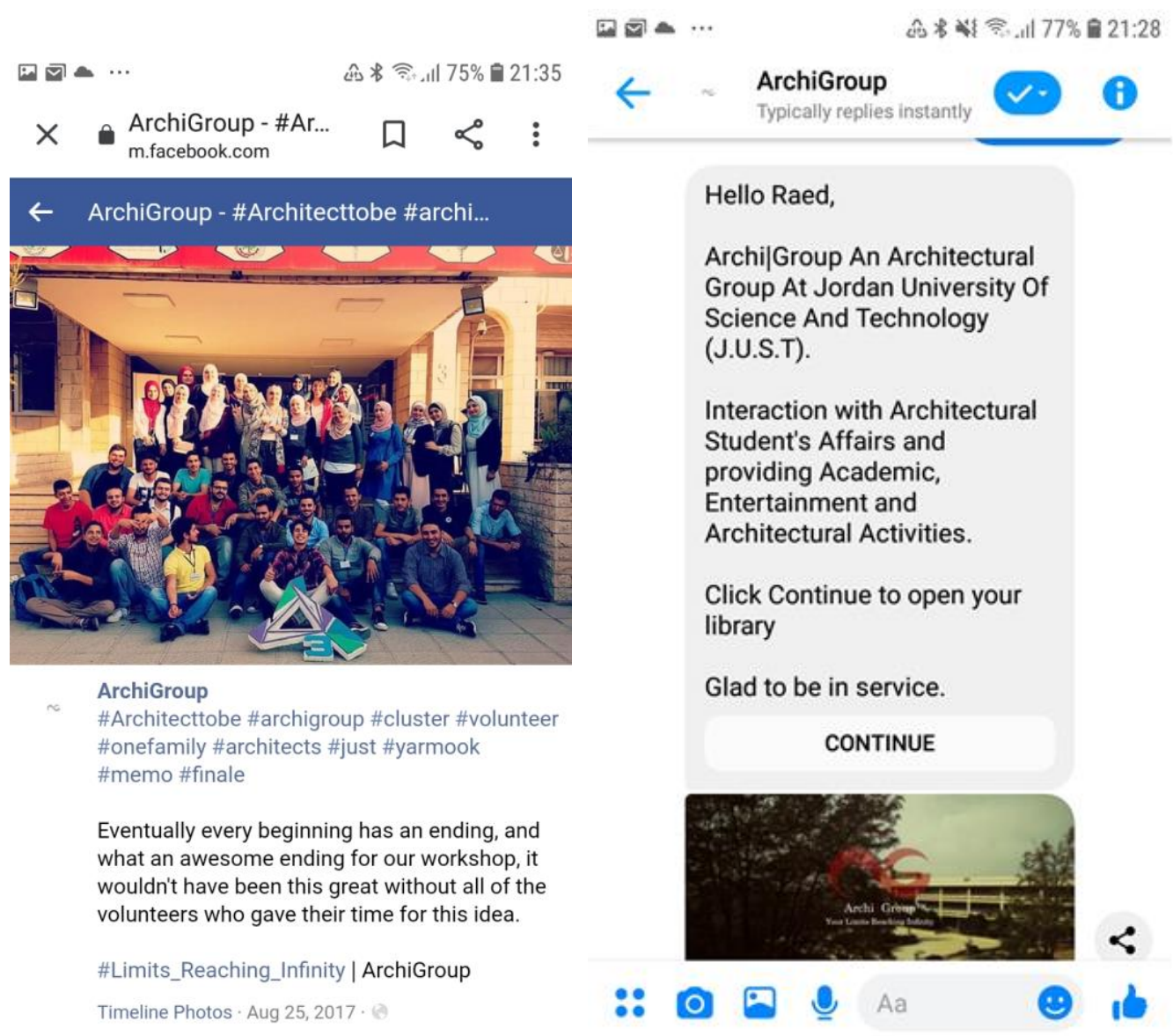

Figure 3. The ArchiGroup Facebook

Source: Authors.

As well as a member, open the ArchiGroup, user's interface will be the group's wall. On this space, almost all interaction happens, since members can equally post whatever they want to share with their virtual community (Figure 4). Files are uploaded, questions are asked, news is announced, opinions are shared and social quotes are exchanged. All comments and replies are posted on the same wall. An extra feature is given for the group administrators to pin a selected posts to be seen at the top of the group's wall. Otherwise, members' interaction decides the arrangements of posts on the wall. Members also contact directly with another member or sub-group of members through their inbox. This adds another direction of communication between members, enhancing the social network and creating nodes of interaction. The last aspect of Sharing in the group's interaction is the spaces of: Events, Photos and Files. Members share several kinds of information within these interfaces. Nevertheless, the group's wall seems to be the most active interface. The tested sample was students of those who interact (or used to) both: virtually in the ArchiGroup cyberspace, and traditionally in the College of Architecture and Design physical space. 


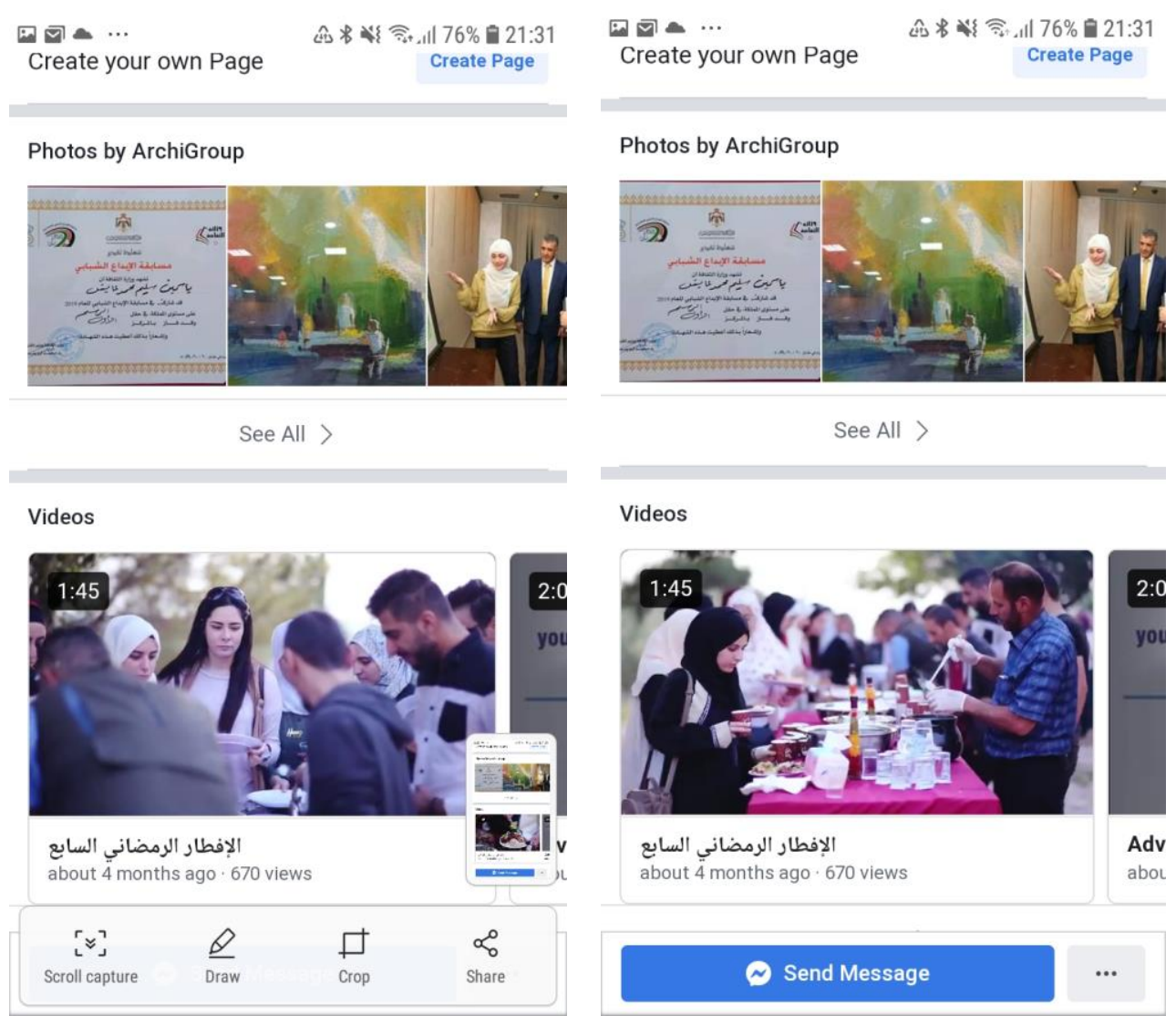

Figure 4. The Group's Wall of the ArchiGroup

Source: Drawing by Authors.

\section{Study Tool}

The study has been built on an e-questionnaire of two main sections: The first section: investigates the demographic properties of the sample, and the second section: investigates their responses towards five main hypotheses. The questionnaire consistency - the harmony between each section's content with its target hypothesis, has been calculated. Cronbach's alpha has been founded to exceed the needed $99 \%$ to consider enough consistency. $93.8 \%$ shows that the questionnaire results are dependable.

\section{Testing}

Pearson and Spearman correlation, the regression coefficient, the coefficient of internal consistency (Cronbach's alpha) and the One Sample T-Test have been used to check the study hypothesis. Also the descriptive methods have been used to reach some information about the study. For each, the repetitions, percentages, related measures of central tendency (the arithmetic mean and mediator) and measures of dispersion (Standard deviation and Interquartile range) were calculated. 


\section{Demographic Properties of the Sample}

In terms of investigating the sample properties, some demographic features were analyzed in the first section of the questionnaire. This section contains questions of general data about the sample and its effectiveness in the study, as shown in Table 1.

Table 1. The General Properties of the Sample

\begin{tabular}{|c|c|c|c|c|}
\hline $\begin{array}{l}\text { Question } \\
\text { number }\end{array}$ & $\begin{array}{c}\text { The } \\
\text { question }\end{array}$ & Possible answers & Number & percentage \\
\hline \multirow[t]{4}{*}{1} & \multicolumn{4}{|l|}{ Gender } \\
\hline & & Female & 122 & $61 \%$ \\
\hline & & Male & 77 & $39 \%$ \\
\hline & & & & $100 \%$ \\
\hline \multirow[t]{8}{*}{2} & \multicolumn{4}{|l|}{ Year } \\
\hline & & First & 10 & $5 \%$ \\
\hline & & Second & 51 & $26 \%$ \\
\hline & & Third & 39 & $20 \%$ \\
\hline & & Fourth & 21 & $11 \%$ \\
\hline & & Fifth & 29 & $15 \%$ \\
\hline & & Graduated & 49 & $25 \%$ \\
\hline & & & & $100 \%$ \\
\hline \multirow[t]{4}{*}{3} & \multicolumn{4}{|c|}{ Are you a member in the Archi-Group on Facebook? } \\
\hline & & Yes & 157 & $79 \%$ \\
\hline & & No & 42 & $21 \%$ \\
\hline & & & & $100 \%$ \\
\hline \multirow[t]{9}{*}{4} & \multicolumn{4}{|c|}{ If not, then why? } \\
\hline & & $\begin{array}{l}\text { I do not have a } \\
\text { Facebook account }\end{array}$ & 0 & $0 \%$ \\
\hline & & $\begin{array}{l}\text { I do not have time } \\
\text { to interact }\end{array}$ & 7 & $20 \%$ \\
\hline & & $\begin{array}{l}\text { I do not like such } \\
\text { interaction between } \\
\text { colleagues }\end{array}$ & 1 & $3 \%$ \\
\hline & & $\begin{array}{l}\text { I prefer } \\
\text { interaction in the } \\
\text { university }\end{array}$ & 4 & $12 \%$ \\
\hline & & $\begin{array}{l}\text { I do not care } \\
\text { about }\end{array}$ & 8 & $24 \%$ \\
\hline & & $\begin{array}{l}\text { I do not know } \\
\text { about it }\end{array}$ & 4 & $12 \%$ \\
\hline & & Other reasons & 10 & $29 \%$ \\
\hline & & & & $100 \%$ \\
\hline \multirow[t]{4}{*}{5} & \multicolumn{4}{|c|}{ What is your role in the group? } \\
\hline & & An administrator & 7 & $4 \%$ \\
\hline & & A member & 159 & $96 \%$ \\
\hline & & & & $100 \%$ \\
\hline
\end{tabular}


As noted in Table $1,71 \%$ of the sample has been in the investigated community for three years or more, which means that the sample was qualified enough to describe their experience. On another dimension, all samples still or were members of both communities, and at least the traditional one of them.

The specific scope of the sample is the shared members of both communities the real and virtual. Therefore, a question about the membership of the virtual community was used to find out the target group of the sample. $79 \%$ of the sample is shared members of both real and virtual communities of the architectural department students at the Jordan University of Science and Technology. In the real community, where students interact face-to-face at the university, their communication network is mostly horizontal. At the virtual community of the same group of the students are different. $4 \%$ of the students are administrators who care about regulating the interaction between the others.

This section of the questionnaire contains also an elective question for those who are not members of the virtual group about the reason not to be. This question was answered by only 34 students (almost $81 \%$ of those who said NO) who mentioned several reasons. The lack of interest and time were the main reasons of $24 \%$ and $20 \%$ of them - respectively, while the other students were distributed between several other reasons.

Next sections of the questionnaire were answered, totally, by shared members of both communities. All mentioned indicates that the sample responses are dependable.

\section{The Descriptive Analysis of the Sample Responses and the Hypotheses Testing}

Testing the First Hypothesis:

Facebook Users Can Create a Community where they Feel a Kind of Membership

The arithmetic mean and the standard deviation for the sample responses about their membership feeling of their Facebook community are shown in Table 2.

As shown in Table 2, the sample shows a tendency towards the agreement with the different statements which indicate the sense of membership in the virtual communities. As shown in the statements 1-3, the sample feels that they are part of their virtual community, where they care about and can spend time to support. The sample shows that its members intend to establish and enhance a solid network of relationships within the virtual version of their group as well as they do with their real one (statements 4-6). In addition, they prefer to hold this network when they join other virtual communities (statement 7 ). 
Table 2. $1^{\text {st }}$ Hypothesis Statements Analysis - Mean and SD

\begin{tabular}{|c|l|c|c|}
\hline \multicolumn{1}{|c|}{ The statement } & Mean & $\begin{array}{c}\text { Standard } \\
\text { deviation }\end{array}$ \\
\hline 1 & I feel as part of this community & 3.800 & 1.184 \\
\hline 2 & I do care about what is going there & 3.395 & 1.249 \\
\hline 3 & $\begin{array}{l}\text { I really want to spend time supporting } \\
\text { different activities there }\end{array}$ & 3.720 & 1.106 \\
\hline 4 & $\begin{array}{l}\text { Contacting people there remembers me that } \\
\text { all community members are connected to } \\
\text { each other }\end{array}$ & 3.834 & 1.170 \\
\hline 5 & $\begin{array}{l}\text { I do trust some members to solve several } \\
\text { issues }\end{array}$ & 3.870 & 1.156 \\
\hline 6 & $\begin{array}{l}\text { There are some members who I can ask for } \\
\text { an advice in important issues }\end{array}$ & 3.728 & 1.088 \\
\hline 7 & $\begin{array}{l}\text { I prefer to be with theses members while } \\
\text { joining other groups }\end{array}$ & 3.210 & 0.858 \\
\hline All statements & $\mathbf{3 . 7 2 8}$ & $\mathbf{1 . 1 1 6}$ \\
\hline
\end{tabular}

Table 3. Applying the Decision Rule on the $1^{\text {st }}$ Hypothesis

\begin{tabular}{|c|c|c|c|c|c|}
\hline $\begin{array}{c}\text { The } \\
\text { arithmetic } \\
\text { mean }\end{array}$ & $\begin{array}{c}\text { Standard } \\
\text { deviation }\end{array}$ & $\begin{array}{c}\text { Calculated T- } \\
\text { value }\end{array}$ & $\begin{array}{c}\text { Scheduled T- } \\
\text { value }\end{array}$ & $\begin{array}{c}\text { Statistical } \\
\text { significance }\end{array}$ & $\begin{array}{c}\text { The } \\
\text { Result }\end{array}$ \\
\hline 3.728 & 3.728 & 5.866 & 2.58 & 000 & Rejected \\
\hline
\end{tabular}

Table 4. Facebook Users Can Create a Community where they Feel a Kind of Membership

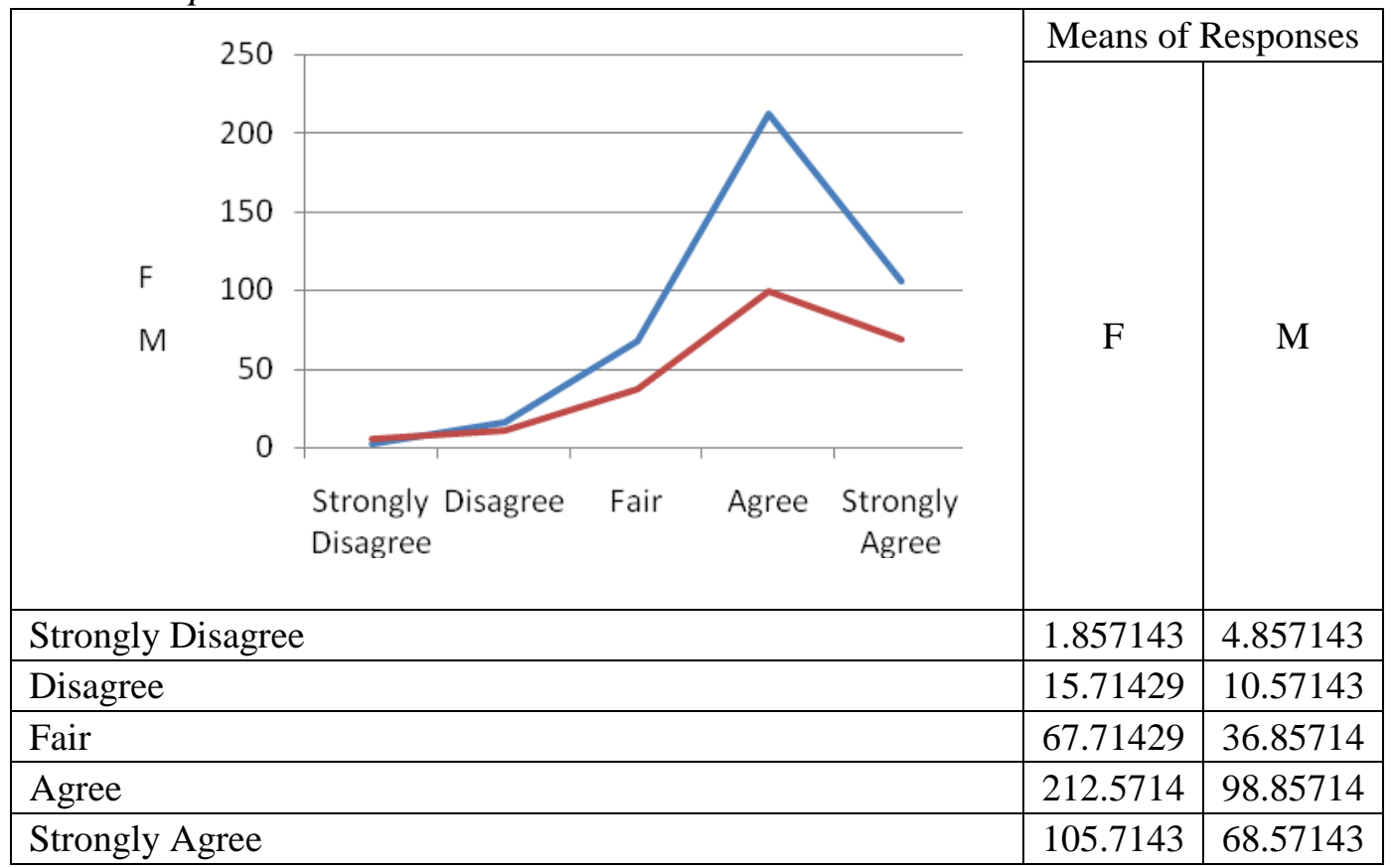


As shown in Table 3, the calculated T-value (5.866) is larger than the scheduled one. Then, according to the decision rule note that $\mathrm{H}_{0}$ is accepted if Calculated T-value was less than the Scheduled T-value, $\mathrm{H}_{0}$ is rejected if Calculated T-value was more than the Scheduled T-value, the zero hypothesis $\left(\mathrm{H}_{0}\right)$ is rejected and the alternative one $\left(\mathrm{H}_{1}\right)$ is accepted, which means that Facebook users can create a community where they feel a kind of membership (Table 4).

Testing the Second Hypothesis:

Space on Facebook can overcome the Time Limitations in the Physical Synonym

Table 5. $2^{\text {nd }}$ Hypothesis Statements Analysis - Mean and SD

\begin{tabular}{|c|l|c|c|}
\hline & \multicolumn{1}{|c|}{ The statement } & Mean & $\begin{array}{c}\text { Standard } \\
\text { deviation }\end{array}$ \\
\hline 1 & $\begin{array}{l}\text { I enter the group after finishing my day at the } \\
\text { university }\end{array}$ & 3.280 & 0.914 \\
\hline 2 & $\begin{array}{l}\text { The group enables us to keep in contact all the } \\
\text { time }\end{array}$ & 4.128 & 1.326 \\
\hline 3 & $\begin{array}{l}\text { I feel it is kind of extension of the university } \\
\text { environment in this group }\end{array}$ & 4.206 & 1.357 \\
\hline 4 & I get benefit as much as I do in the university & 3.485 & 0.977 \\
\hline All statements & $\mathbf{3 . 7 7 5}$ & $\mathbf{1 . 1 4 4}$ \\
\hline
\end{tabular}

The second hypothesis aims at investigating the perception of time value in the cyberspace of the ArchiGroup on Facebook. Cyberspace can overcome the time limitations in the physical synonym. That what the sample indicates. The sample agrees that the group enables them to keep in touch all the time (statement 2), and to feel an extension of the university environment and many of its benefits (statements 3-4). That is why the group becomes an attractive environment to enter after finishing their day at the university (statement 1) (Table 5).

Table 6. Applying the Decision Rule on the $2^{\text {nd }}$ Hypothesis

\begin{tabular}{|c|c|c|c|c|c|}
\hline $\begin{array}{c}\text { The } \\
\text { arithmetic } \\
\text { mean }\end{array}$ & $\begin{array}{c}\text { Standard } \\
\text { deviation }\end{array}$ & $\begin{array}{c}\text { Calculated } \\
\text { T-value }\end{array}$ & $\begin{array}{c}\text { Scheduled T- } \\
\text { value }\end{array}$ & $\begin{array}{c}\text { Statistical } \\
\text { significance }\end{array}$ & $\begin{array}{c}\text { The } \\
\text { Result }\end{array}$ \\
\hline 3.775 & 1.144 & 6.076 & 2.58 & 000 & Rejected \\
\hline
\end{tabular}

As shown in Table 6, the calculated T-value (6.076) is larger than the scheduled one. Then, according to the decision rule, the zero hypothesis $\left(\mathrm{H}_{0}\right)$ is rejected and the alternative one $\left(\mathrm{H}_{3}\right)$ is accepted, which means that Space on Facebook can overcome the time limitations in the physical synonym (Table 7). 
Table 7. Space on Facebook can overcome the Time Limitations in the Physical Synonym

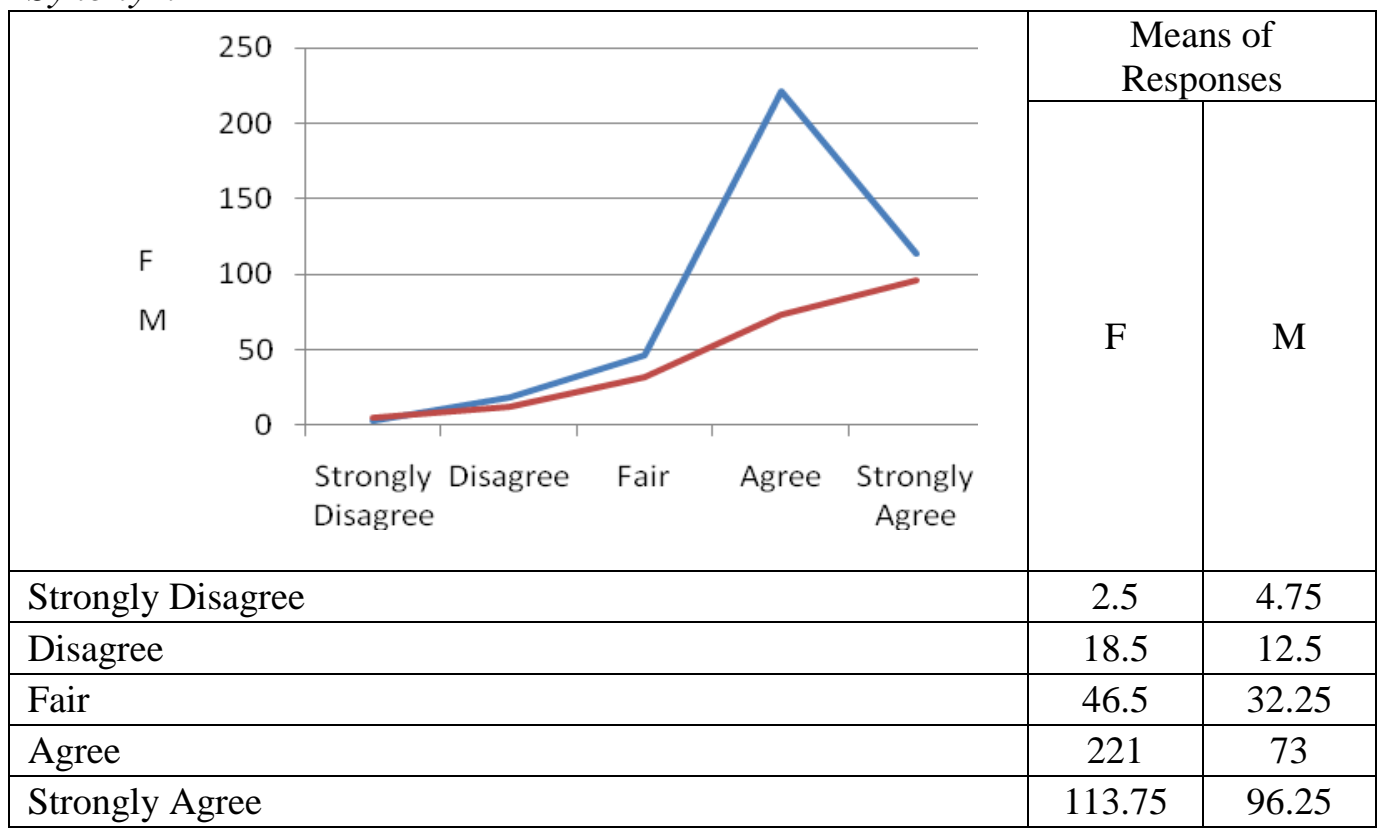

Testing the Third Hypothesis:

Facebook Members Feel the Importance of Temporal Dimension in their Space

This section includes two questions of descriptive analysis (Table 8).

Table 8. $3^{\text {rd }}$ Hypothesis Statements Descriptive Analysis - Number and Percentage

\begin{tabular}{|c|c|c|c|c|}
\hline $\begin{array}{l}\text { Question } \\
\text { number }\end{array}$ & $\begin{array}{l}\text { The } \\
\text { question }\end{array}$ & Possible answers & Number & percentage \\
\hline \multirow[t]{8}{*}{1} & \multicolumn{4}{|c|}{ During the week, I join the group... } \\
\hline & & $\begin{array}{l}\text { In the morning, before going to } \\
\text { university }\end{array}$ & 10 & $6 \%$ \\
\hline & & While being in the university & 9 & $6 \%$ \\
\hline & & $\begin{array}{l}\text { Just after arriving home from } \\
\text { university }\end{array}$ & 19 & $12 \%$ \\
\hline & & In the evening & 94 & $59 \%$ \\
\hline & & After mid night & 10 & $6 \%$ \\
\hline & & $\begin{array}{l}\text { I do not check the group during } \\
\text { the week }\end{array}$ & 17 & $11 \%$ \\
\hline & & & & $100 \%$ \\
\hline \multirow[t]{7}{*}{2} & \multicolumn{4}{|c|}{ During the weekend and other vacations, I enter the group. } \\
\hline & & $\begin{array}{l}\text { In the morning, just after waking } \\
\text { up }\end{array}$ & 6 & $4 \%$ \\
\hline & & Several times during the day & 84 & $52 \%$ \\
\hline & & In the evening & 48 & $30 \%$ \\
\hline & & After mid night & 4 & $2 \%$ \\
\hline & & $\begin{array}{l}\text { I do not check the group during } \\
\text { the weekend }\end{array}$ & 19 & $12 \%$ \\
\hline & & & & $100 \%$ \\
\hline
\end{tabular}


The sample responses indicate their tendency to extend their environment out of the college borders. This explains the majority ( $77 \%$ in total) joining the group after being in the college during the week, and all along the day on the weekend. Only $11 \%$ and $12 \%$ seem to be satisfied with the physical space of the college, and do not join their cyberspace during the week and the weekend respectively. The variety in responses shows different perceptions for joining the group according the temporal factor. This factor was the target of the next two questions (Table 9).

Table 9. $3^{\text {rd }}$ Hypothesis Statements Analysis - Mean and SD

\begin{tabular}{|c|l|c|c|}
\hline & \multicolumn{1}{|c|}{ The statement } & Mean & Standard deviation \\
\hline 1 & $\begin{array}{l}\text { If I want to share a post, I choose a specific } \\
\text { time to do }\end{array}$ & 3.213 & 0.838 \\
\hline 2 & Members interaction changes along the day & 3.944 & 1.224 \\
\hline \multicolumn{2}{|l|}{ All statements } & $\mathbf{3 . 5 7 8}$ & $\mathbf{1 . 0 3 1}$ \\
\hline
\end{tabular}

The sample responses indicate their agreement of the temporal time effectiveness in the cyberspace. They agree that member interaction changes along the day (statement 2). That is why they choose specific time to ensure enough interaction for their posts (statement 1).

Table 10. Applying the Decision Rule on the $3^{\text {rd }}$ Hypothesis

\begin{tabular}{|c|c|c|c|c|c|}
\hline $\begin{array}{c}\text { The } \\
\text { arithmetic } \\
\text { mean }\end{array}$ & $\begin{array}{c}\text { Standard } \\
\text { deviation }\end{array}$ & $\begin{array}{c}\text { Calculated T- } \\
\text { value }\end{array}$ & $\begin{array}{c}\text { Scheduled } \\
\text { T-value }\end{array}$ & $\begin{array}{c}\text { Statistical } \\
\text { significance }\end{array}$ & $\begin{array}{c}\text { The } \\
\text { Result }\end{array}$ \\
\hline 3.578 & 1.031 & 5.311 & 2.58 & 000 & Rejected \\
\hline
\end{tabular}

Table 11. Facebook Members Feel the Importance of Temporal Dimension in their Space

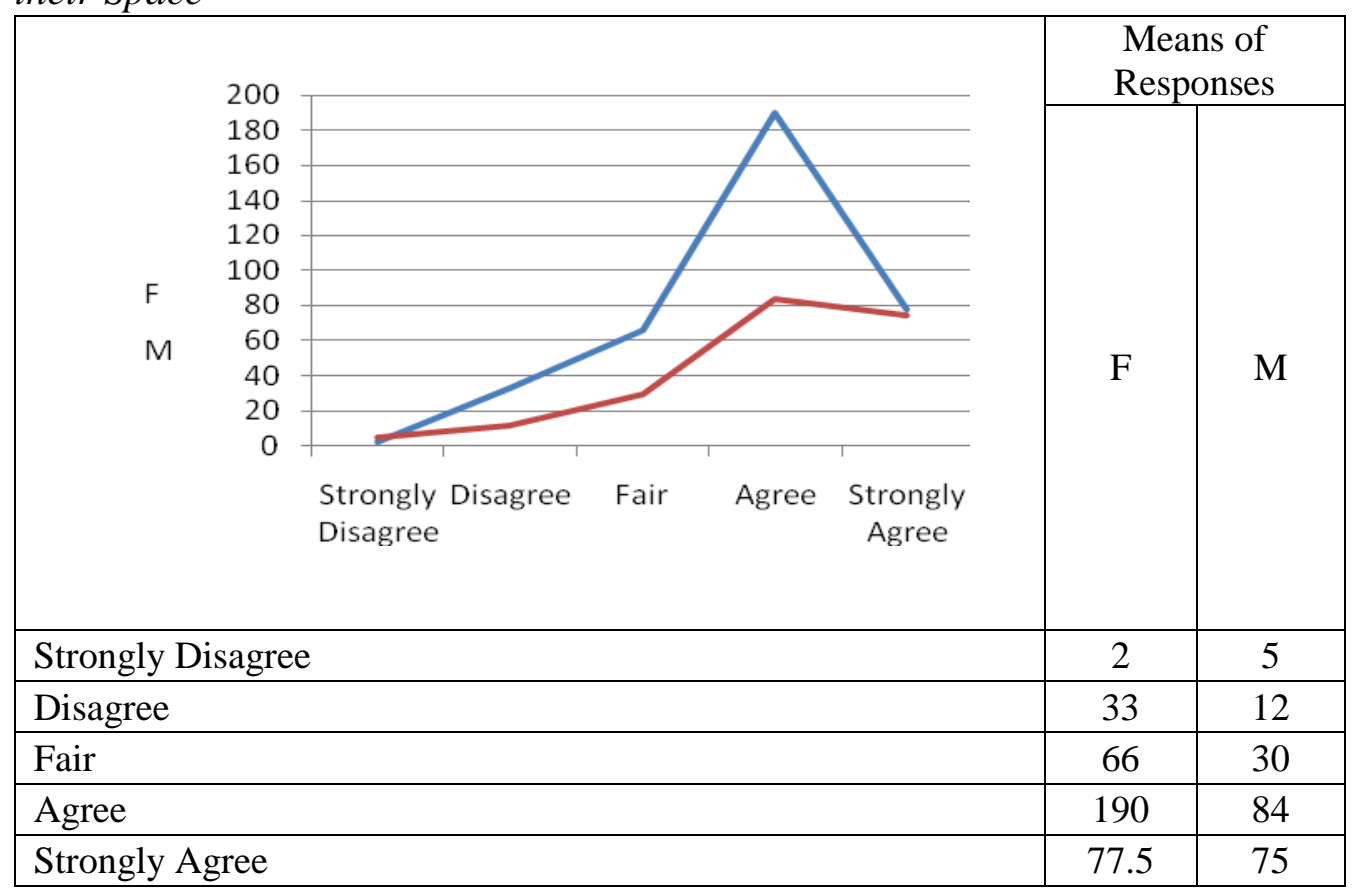


As shown in Table 10, the calculated T-value (5.311) is larger than the scheduled one. Then, according to the decision rule, the zero hypothesis $\left(\mathrm{H}_{0}\right)$ is rejected and the alternative one $\left(\mathrm{H}_{6}\right)$ is accepted, which means that Facebook members feel the importance of temporal dimension in their space (Table 11).

Testing the Fourth Hypothesis: Facebook Members Feel their Space

Table 12. $4^{\text {th }}$ Hypothesis Statements Analysis - Mean and SD

\begin{tabular}{|c|c|c|c|}
\hline & The statement & Mean & $\begin{array}{l}\text { Standard } \\
\text { deviation }\end{array}$ \\
\hline 1 & $\begin{array}{l}\text { There is more intimacy on the virtual group } \\
\text { than the real one }\end{array}$ & 2.714 & 0.665 \\
\hline 2 & $\begin{array}{l}\text { There is more openness on the virtual group } \\
\text { than the real one }\end{array}$ & 3.550 & 1.027 \\
\hline 3 & Students interact more on the virtual group & 3.694 & 1.150 \\
\hline 4 & $\begin{array}{l}\text { The college staff is closer to the students on the } \\
\text { virtual group }\end{array}$ & 3.338 & 0.943 \\
\hline 5 & $\begin{array}{l}\text { The virtual group members do not accept the } \\
\text { opposite opinions as they do in real one }\end{array}$ & 3.125 & 0.826 \\
\hline \multicolumn{2}{|c|}{ All statements } & 3.284 & 0.922 \\
\hline
\end{tabular}

The forth hypothesis aims at investigating the sample sensation about their cyberspace. The statements of this hypothesis asked the sample to compare their cyberspace to their physical one in terms of: intimacy, openness, interaction and perceived distances between members. The sample responses show that the cyberspace seems to be more open than the physical one (statement 2), so that they interact more within (statement 3). This openness encourages the students to step closer to the college staff (statement 4), but that did not make it more intimate (statement 1) or increase the acceptance of the different opinions (statement 5) (Table 12).

Table 13. Applying the Decision Rule on the $4^{\text {th }}$ Hypothesis

\begin{tabular}{|c|c|c|c|c|c|}
\hline $\begin{array}{c}\text { The } \\
\text { arithmetic } \\
\text { mean }\end{array}$ & $\begin{array}{c}\text { Standard } \\
\text { deviation }\end{array}$ & $\begin{array}{c}\text { Calculated } \\
\text { T-value }\end{array}$ & $\begin{array}{c}\text { Scheduled } \\
\text { T-value }\end{array}$ & $\begin{array}{c}\text { Statistical } \\
\text { significance }\end{array}$ & The Result \\
\hline 3.284 & 0.922 & 4.423 & 2.58 & 000 & Rejected \\
\hline
\end{tabular}

As shown in Table 13, the calculated T-value (4.423) is larger than the scheduled one. Then, according to the decision rule, the zero hypothesis $\left(\mathrm{H}_{0}\right)$ is rejected and the alternative one $\left(\mathrm{H}_{8}\right)$ is accepted, which means Facebook members feel their space (Table 14). 
Table 14. Facebook Members Feel their Space

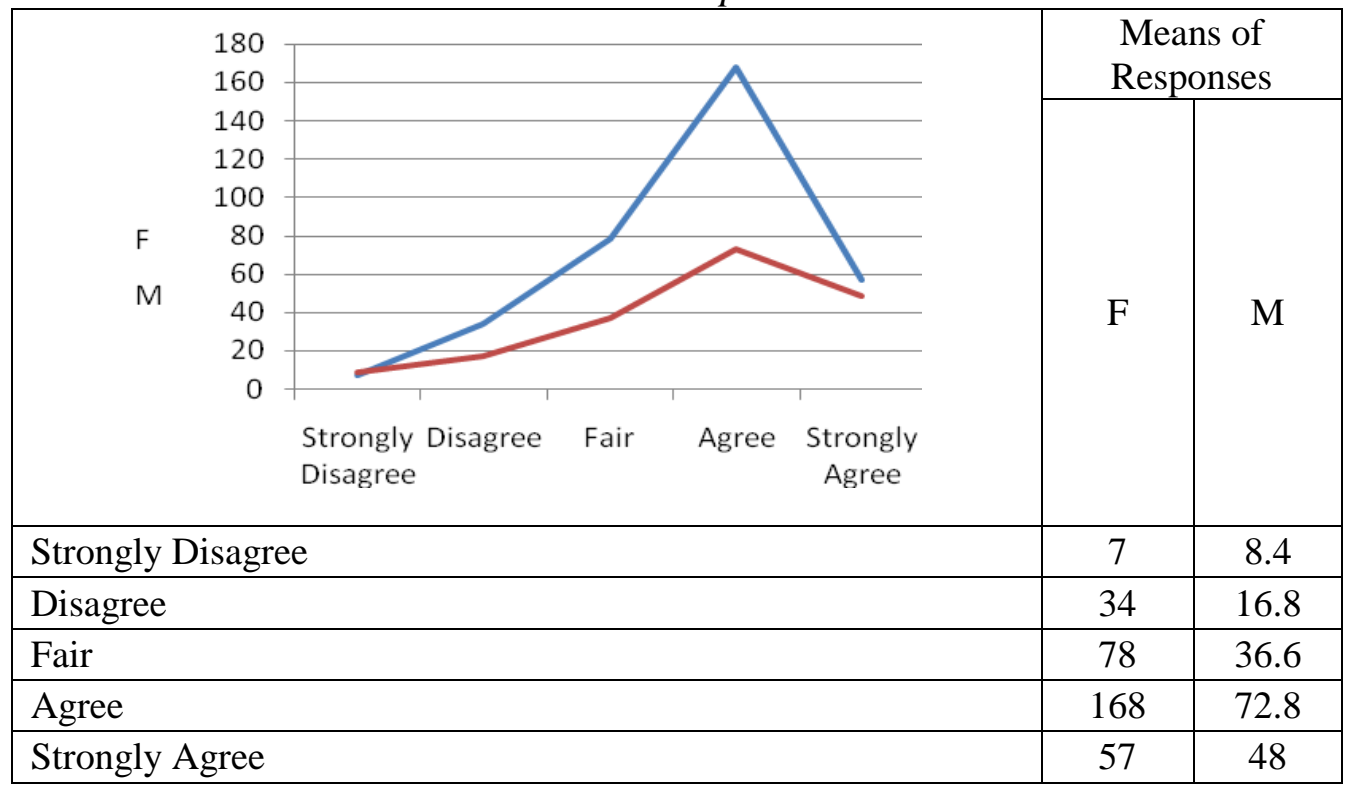

Testing the Fifth Hypothesis:

Facebook Members Feel the Physical Features of their Space

After the sample indicates that, they feel a spatial dimension of their cyberspace, the last hypothesis aims at investigating their responses towards the physical features of this space. The statements of this hypothesis varied to include some statistical and descriptive responses (Table 15).

Table 15. $5^{\text {th }}$ Hypothesis Statements Analysis - Mean and SD

\begin{tabular}{|c|c|c|c|}
\hline & The statement & Mean & $\begin{array}{l}\text { Standard } \\
\text { deviation }\end{array}$ \\
\hline 1 & $\begin{array}{l}\text { I feel connected to the space which contains the } \\
\text { group virtually }\end{array}$ & 3.385 & 0.975 \\
\hline 2 & $\begin{array}{l}\text { I feel this space is very similar to its physical } \\
\text { synonym in the college }\end{array}$ & 3.300 & 0.922 \\
\hline 3 & $\begin{array}{l}\text { Generally, I feel the reality of this cyberspace of } \\
\text { the group }\end{array}$ & 3.559 & 1.076 \\
\hline 4 & $\begin{array}{l}\text { Facebook uses one single interaction surface } \\
\text { form for its all pages, regardless of its topic or } \\
\text { content. } \\
\text { If you were asked to re-design the Facebook } \\
\text { interaction surface, would you categorize the } \\
\text { different pages according to its uses? }\end{array}$ & 3.200 & 0.919 \\
\hline 5 & I feel some architectural features & 4.025 & 1.263 \\
\hline 6 & I feel the physical reality of the space & 3.870 & 1.210 \\
\hline 7 & $\begin{array}{l}\text { While dealing with such questionnaire, I prefer } \\
\text { the e-form }\end{array}$ & 4.261 & 1.419 \\
\hline \multicolumn{2}{|c|}{ All statements } & 3.657 & 1.112 \\
\hline
\end{tabular}


Seven statistical statements support this hypothesis through investigating the sample's attitude towards the physical featuring of cyberspace. The sample shows a kind of connecting to a space which they feel, somehow, real and similar to their physical one at the college (statements 1-3). The sample noted negatively the total similarity of the Facebook pages regardless their content and they would to redesign them into more identified themes (statement 4). Their attitude to feel the cyberspace as a real space encourages them to show a tendency towards using architectural features in redesigning Facebook pages (statement 5). That is an approach, as the sample says, to increase the feeling of cyberspace reality (statement 7).

Finally, a question was added to compare both spaces in a simple specific example of activities. The sample was asked to compare dealing with the questionnaire form physically or in a cyber version. The sample significantly prefers the e-forms.

Table 16. Applying the Decision Rule on the $5^{\text {th }}$ Hypothesis

\begin{tabular}{|c|c|c|c|c|c|}
\hline $\begin{array}{c}\text { The } \\
\text { arithmetic } \\
\text { mean }\end{array}$ & $\begin{array}{c}\text { Standard } \\
\text { deviation }\end{array}$ & $\begin{array}{c}\text { Calculated T- } \\
\text { value }\end{array}$ & $\begin{array}{c}\text { Scheduled T- } \\
\text { value }\end{array}$ & $\begin{array}{c}\text { Statistical } \\
\text { significance }\end{array}$ & $\begin{array}{c}\text { The } \\
\text { Result }\end{array}$ \\
\hline 3.657 & 1.112 & 5.686 & 2.58 & 000 & Rejected \\
\hline
\end{tabular}

As shown in Table 16, the calculated T-value (5.686) is larger than the scheduled one. Then, according to the decision rule, the zero hypothesis $\left(\mathrm{H}_{0}\right)$ is rejected and the alternative one $\left(\mathrm{H}_{9}\right)$ is accepted, which means that Facebook members feel the physical features of their space. Also, this section includes questions of descriptive analysis.

Table 17. $5^{\text {th }}$ Hypothesis $-A-$ Statements Descriptive Analysis - Number and Percentage

\begin{tabular}{|c|c|c|c|c|}
\hline $\begin{array}{l}\text { Question } \\
\text { number }\end{array}$ & $\begin{array}{l}\text { The } \\
\text { question }\end{array}$ & Possible answers & Number & percentage \\
\hline \multirow[t]{8}{*}{6} & \multicolumn{4}{|c|}{$\begin{array}{l}\text { What features you will use to identify the different pages? (you can choose } \\
\text { more than one) }\end{array}$} \\
\hline & & Page elements & 69 & $18 \%$ \\
\hline & & Page layout & 104 & $27 \%$ \\
\hline & & Available features & 65 & $17 \%$ \\
\hline & & Color theme & 80 & $21 \%$ \\
\hline & & Page photo & 55 & $15 \%$ \\
\hline & & Other (please mention) & 8 & $2 \%$ \\
\hline & & & & $100 \%$ \\
\hline
\end{tabular}

As the sample shows a tendency towards giving some architectural features, they were asked to choose out of some possible features. The page layout was the first choice with a $27 \%$ of the sample, followed by the color theme with $21 \%$. The page elements and available features were the choice of $18 \%$ and $17 \%$ respectively. In the last rank, the page photo was the choice of $15 \%$ of the sample. $2 \%$ of the sample had other alternatives. Their suggestions varies to include virtual 
sketching tool, audio or video hangout for important advertisements, viewer for ebooks (like pdf viewer), highlighting tool for coloring text or formatting it, graphical tools for expressing thoughts, special zones, backgrounds, applications, and other elements to identify the page more specifically (Table 17).

Lastly, the sample was asked to compare their cyberspace with different physical spaces. The statements included specific activities members usually apply effectively on their cyberspace. For each, the sample was asked to choose a physical space to hold the activity within for two cases of 50 and 200 participants. Five alternative physical spaces were given as a synonym for the cyber milieu which contains them usually: outdoor plaza, theater, lecture room, public space and an indoor square (Table 18).

Table 18. $5^{\text {th }}$ Hypothesis $-B$ - Statements Descriptive Analysis - Number and Percentage

\begin{tabular}{|c|c|c|c|c|}
\hline & Participants & Possible answers & Number & percentage \\
\hline $8-\mathrm{A}$ & \multicolumn{4}{|c|}{$\begin{array}{l}\text { (Social) } \\
\text { The group members meet in a celebrating day includes several activities to } \\
\text { enhance the personal relationships between the members. } \\
\text { The day is prepared after some personal events for a number of members. } \\
\text { Sharing common statements in such events is dominant in this activity. }\end{array}$} \\
\hline & \multirow{6}{*}{50} & Outdoor Plaza & 27 & $17 \%$ \\
\hline & & Theater & 14 & $9 \%$ \\
\hline & & Lecture Room & 10 & $6 \%$ \\
\hline & & Public space & 11 & $7 \%$ \\
\hline & & Indoor square & 96 & $61 \%$ \\
\hline & & & & $100 \%$ \\
\hline & \multirow{6}{*}{200} & Outdoor Plaza & 66 & $43 \%$ \\
\hline & & Theater & 39 & $25 \%$ \\
\hline & & Lecture Room & 8 & $5 \%$ \\
\hline & & Public space & 14 & $9 \%$ \\
\hline & & Indoor square & 28 & $18 \%$ \\
\hline & & & & $100 \%$ \\
\hline
\end{tabular}

The first example was for a social event. Social statements are widely exchanged on the Facebook group. The members find their cyberspace effective to share several quotes in different events. It lets them be closer to each other and to contact casually. This question aims at describing a physical space, which acts as effective as the cyber one for social interaction.

50 participants, the sample, significantly (78\% in total), preferred casualty and horizontality in describing the space to contain such activity. Their attitude was clear in choosing indoor square and outdoor plaza respectively. The other three alternatives were less preferred since they miss the mentioned casualty and horizontality, when talking about theaters and lecture rooms, and the privacy of the group when talking about public spaces.

Even when the participants have been doubled, the horizontality in contacting network still was preferred. It was only moved to outdoor with $43 \%$ who chose outdoor plaza. Even indoor square still works for $18 \%$ of the sample. Selecting the 
theater to be the preferred alternative of $25 \%$ of the sample indicates their tendency to ensure a kind of management carried by a selected sub-group. This indicates a transition in the notion of horizontality into more hierarchal network.

Table 19. $5^{\text {th }}$ Hypothesis $-C$ - Statements Descriptive Analysis - Number and Percentage

\begin{tabular}{|c|c|c|c|c|}
\hline \multirow[t]{13}{*}{$8-B$} & \multicolumn{4}{|c|}{$\begin{array}{l}\text { (Cultural) } \\
\text { The group members are preparing for a seminar for a subject related to their } \\
\text { age group. It is not related to the professional theme which gather them. } \\
\text { The seminar is managed by the members themselves. There is no VIP guests. }\end{array}$} \\
\hline & \multirow{6}{*}{50} & Outdoor Plaza & 14 & $9 \%$ \\
\hline & & Theater & 21 & $13 \%$ \\
\hline & & Lecture Room & 78 & $50 \%$ \\
\hline & & Public space & 12 & $8 \%$ \\
\hline & & Indoor square & 32 & $20 \%$ \\
\hline & & & & $100 \%$ \\
\hline & \multirow{6}{*}{200} & Outdoor Plaza & 22 & $14 \%$ \\
\hline & & Theater & 95 & $61 \%$ \\
\hline & & Lecture Room & 11 & $7 \%$ \\
\hline & & Public space & 12 & $8 \%$ \\
\hline & & Indoor square & 16 & $10 \%$ \\
\hline & & & & $100 \%$ \\
\hline
\end{tabular}

Table 20. $5^{\text {th }}$ Hypothesis $-D$ - Statements Descriptive Analysis - Number and Percentage

\begin{tabular}{|c|c|c|c|c|}
\hline \multirow[t]{13}{*}{$8-\mathrm{C}$} & \multicolumn{4}{|c|}{$\begin{array}{l}\text { (Academic) } \\
\text { The group members prepare for a day in which they will show some of } \\
\text { their projects to share a communal feedback. } \\
\text { Every member is allowed to show a poster which include shots of several } \\
\text { design projects, give and get comments of other members. }\end{array}$} \\
\hline & \multirow{6}{*}{50} & Outdoor Plaza & 17 & $11 \%$ \\
\hline & & Theater & 11 & $7 \%$ \\
\hline & & Lecture Room & 50 & $32 \%$ \\
\hline & & Public space & 10 & $6 \%$ \\
\hline & & Indoor square & 68 & $44 \%$ \\
\hline & & & & $100 \%$ \\
\hline & \multirow{6}{*}{200} & Outdoor Plaza & 44 & $28 \%$ \\
\hline & & Theater & 47 & $30 \%$ \\
\hline & & Lecture Room & 27 & $17 \%$ \\
\hline & & Public space & 13 & $8 \%$ \\
\hline & & Indoor square & 26 & $17 \%$ \\
\hline & & & & $100 \%$ \\
\hline
\end{tabular}

The second example was for a cultural event. This is a very important sector of discussions on cyberspace. Usually, Facebook users meet online to discuss a topic of interest. The given example aims to transfer this discussion into a physical space. The sample were asked to select the one where they think a successful discussion could be hold as well as in the cyberspace. In such activity, the sample 
shows a significant tendency towards spaces where every participant can get a space as equal as to everyone else, talk and listen regularly. That is what the responses, which choose the lecture room (50\%) and theater (61\%), for a 50 and 200 participant cultural event, indicate (Tables 19 and 20).

The second choices of the sample, indoor square $(20 \%)$ and outdoor plaza (14\%) for a 50 and 200 participant cultural event, show the dominancy of the horizontal relationships on the members' perception of their cyberspace success.

Table 21. Facebook Members Feel the Physical Features of their Space

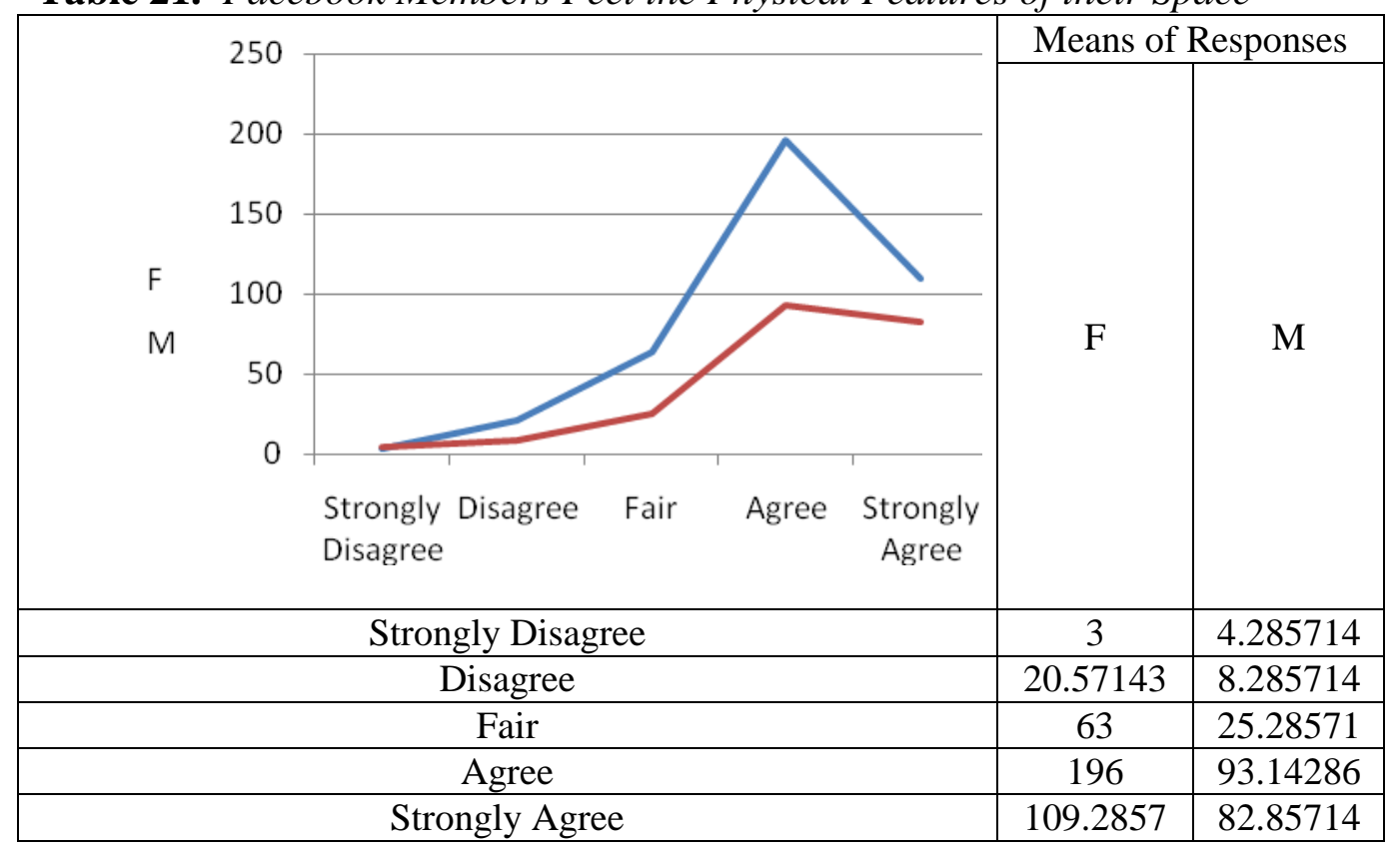

The professional ties are very essential in the case of ArchiGroup. Their physical space contains most of their academic activities. Facebook users usually share their products - design projects in this case, to get communal feedback virtually. The last example aims at transferring this experience into a physical space, saving the communality as a major feature of sharing comments. The sample choices were not very clear. They give convergent percentages for the different alternatives. However, the main shared factor of them that everyone want to get a space just as everyone else, and the casualty still strongly appears (Table 21).

\section{Results}

The sample responses of the students of College of Architecture and Design in Jordan University of Science and Technology indicated their ability to create virtual community, where they feel a kind of membership, and which affect them positively. This community is contained with a cyberspace, which they can feel. This space can overcome the time limitations in the physical synonym, providing more liberal opportunities of interaction. The sample describes their cyberspace, 
where they found temporal factor to be essential, as an affordable space. In different levels, the cyberspace meets their needs in: general discussions, advertising, professional and emotional interaction.

Finally, the sample responses indicate their ability to feel the physical features of the cyberspace. They have the ability to compare it to several types of physical spaces, indicating many features they see as a source of success for the cyberspace. The only hypothesis which has been rejected by the sample is that talking about the feeling of control on their cyberspace. There were no genderbased differences in the sample responses. For some hypotheses females seem to be more motivated than males - have a larger mean motivational level, for other hypotheses males were more motivated

\section{Conclusions}

The research discussed the forming of community with a spatial sense. In Facebook, users start to establish a property through which they enter several networks of interest. Initiating relationships is found to be a significant use of Facebook, but maintaining them is the dominant. These relationships have a good chance to maintain, even while being in distance. But, most of them are found to be casual without enough intimacy for maintaining close relationships.

The research also reveals Facebook intersections with real communities, through which users feel the reality of their networks. New online connections are created on Facebook, and in many cases they take place in offline relationships. On the other hand, offline relationships are enhanced while users employ Facebook's surveillance to find out information about people with whom they have any sort of connection. For these purposes, Facebook users are provided with both, public and private areas for all types of needed contacting (according to their personalities and experiences on network). Therefore, Individuals can communicate and share information instantly and independently from their geographical location, with selected networks of different sizes.

Based on the results, the findings of the research recommend designers to consider the success of cyberspace while designing the physical versions. In addition, the research seems applicable on different models that employ different variables to investigate a mechanism of producing a physical space as productive as the cyber version, achieving the real version of "participation".

\section{Bibliography}

Bender, T. Community and Social Change in America. New Brunswick, New Jersey: Rutgers University Press, 1978.

Brint, S., M. F. Contreras and M. T. Matthews. "Socialization Messages in Primary Schools: An Organizational Analysis.” Sociology of Education 74, no. 3 (2001): 157 180.

Crow, G. and A. Graham. Community Life: An Introduction to Local Social Relations. New York, USA: Harvester-Wheatsheaf, 1994. 
Doyle, S., M. Dodge and A. Smith. "The Potential of Web-Based Mapping and Virtual Reality/Technologies for Modelling Urban Environments." Computers, Environment and Urban Systems 22, no. 2 (1998): 137-155.

Hollingshead, A. B. Elmtown"s Youth, The Impact of Social Classes on Adolescents. New York: John Wiley and Sons, Inc., 1949.

Hunter, D. Cyberspace as Place and the Tragedy of the Digital Anticommons. California: California Law Review, Inc., 2003.

Mitchell, W. J. City of Bits: Space, Place, and the Infobahn. The MIT Press, 1996.

Muniz A. M., Jr. and T. C. O'Guinn. "Brand Community." Journal of Consumer Research 27, no. 4 (2001): 412-432.

Novak, M. "Liquid Architectures in Cyberspace." In Cyberspace: First Steps. Edited by Michael Benedikt. Cambridge, Massachusetts/London, England: MIT Press, 1993, 248-251.

Rakhshandehroo, M., M. J. Mohd Yusof and A. Sahrakar. "Terminology of Urban Open and Green Spaces." $11^{\text {th }}$ ASEAN Postgraduate Seminar, APGS 2017. Faculty of Built Environment, University of Malaya, Malaysia, 2017.

Wellman, B. and S. D. Berjowitz (Editors). Social Structures: A Network Approach. New York, London: Cambridge University Press, 1988. 
